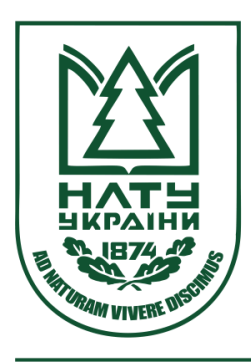

Науковий вісник НлтУ України Scientific Bulletin of UNFU

https://nv.nltu.edu.ua

https://doi.org/10.15421/40280812

$@ \bowtie$ Correspondence author

Article received 02.10.2018 p.

Article accepted 25.10.2018 p.

S. B. Kovalevskii

УДК 630*2:343.3/.7:553.99(477.81)

В. В. Легкий, С. Б. Ковалевський

Національний університет біоресурсів і природокористування України, м. Київ, Украӥна

\title{
ТИПОЛОГІЧНЕ ОЦІНЮВАННЯ ЛІСОВИХ МАСИВІВ ДУБРОВИЦЬКОГО ЛІСНИЦТВА, ПОРУШЕНИХ УНАСЛІДОК НЕСАНКЦІОНОВАНОГО ВИДОБУТКУ БУРШТИНУ
}

\begin{abstract}
Наведено результати дослідження території та лісових насаджень Дубровицького лісництва, ушкоджених внаслідок незаконного видобутку бурштину. З'ясовано масштаби антропізації типів лісорослинних умов, на підстаі чого виокремлено найбільш деградовані з них. Досліджено площі порушених лісових земель і встановлено їх відсоткове співвідношення до загальної площі кварталів Дубровицького лісництва. Наведено коротку характеристику окремих едатопів. Досліджено та проаналізовано співвідношення між порушеними площами та віковою складовою деревостану. Виділено групи віку деревостанів, що зазнали найбільшого антропогенного перетворення внаслідок несанкціонованого промислу. Визначено супутні проблеми, що пов'язані з видобутком бурштину. Встановлено розподіл порушених площ між групами віку та типами лісорослинних умов на особливо захисних лісових ділянках. Охарактеризовано закономірності порушення територій особливо захисних лісових ділянок, що призводить до зникнення рідкісних диких тварин і рослин, втрати захисних функцій лісу, реліктових насаджень та пам'яток історії. Виокремлено негативні наслідки для лісогосподарської галузі, виникнення яких пов'язано з видобутком бурштину. Перелічено лісівницькі втрати, яких зазнає підприємство за рахунок процвітання несанкціонованого промислу. Проаналізовано потенційну можливість природного поновлення на антропізованих площах.
\end{abstract}

Ключові слова: тип лісорослинних умов; антропізація; бурштин.

Вступ. Дослідження типології лісу є доволі актуальним напрямом лісової галузі. Основи знань з типології лісорослинного комплексу є ключовою ланкою в раціональному веденні лісового господарства. Типологія поєднує в собі широкий спектр лісівничих, екологічних та фізіологічних взаємозв'язків рослинних угрупувань (Poiasniuvalnyi lyst, 2002; Svyrydenko, Babich \& Kyrychok, 2008).

Проблема, яка виникла в лісових масивах Дубровицького району внаслідок несанкціонованого видобутку бурштину, сприяє зміні лісорослинних умов на цих територіях. На площах, де відбувався нелегальний промисел, спостерігають значні перетворення у структурі та мінеральному складі грунтового шару лісових земель, повністю або частково знищується живий надгрунтовий покрив, підлісок, підріст зазнає значного перетворення умов місцезростання та антропогенного тиску. Порушення екологічної рівноваги лісу на різних етапах біологічного розвитку може призвести до незворотних наслідків у лісогосподарській галузі (Taxation Description, 2009; Spur \& Barness, 1984).

Вивчення типології порушених лісових ландшафтів Дубровицького району дає змогу оцінити весь спектр лісівничих проблем, які постали перед працівниками галузі, та визначити пріоритетні заходи щодо врегулю- вання цієї ситуації (Lisovyi kodeks Ukrainy, 1994; Postanova KMU, 2016).

Аналіз останніх досліджень та публікацій. На сьогодні проблема, яка постала перед жителями як Дубровицького району, так і всієї Рівненської області, є маловивченою й потребує негайного реагування збоку відповідних державних органів. Ця проблема набула розголосу не тільки на території України, а й за ії межами. Останнім часом з'являється дедалі більше наукових видань та публікацій, що стосуються несанкціонованого видобутку бурштину на територіях Рівненської, Житомирської та Волинської областей. Відповідна проблема $є$ перспективним об'єктом наукових досліджень. Доволі цікавими на сьогодення $є$ наукові дослідження М. М. Казимира, Т. Ю. Бедернічека "Рекультивація земель порушених внаслідок видобутку бурштину на Поліссі: проблеми та перспективи" (Kazymyr \& Bedernichek, 2017) та П. П. Надточія "Еколого-економічна оцінка впливу діяльності пов'язаної з незаконним видобуванням бурштину на стан довкілля Житомирщини" (Nadtochii, 2015). У зазначених вище публікаціях оцінено екологічну ситуацію окремих територій, які зазнали антропогенного навантаження внаслідок несанкціонованого видобутку бурштину, та запропоновано способи рекультивації деградованих земель (Svyrydenko, Babich

\section{Інформація про авторів:}

Легкий Василь Віталійович, студент ННІ ЛіСПГ. Email: legkii.vasil@ukr.net

Ковалевський Сергій Борисович, д-р с.-г. наук, професор, кафедра ботаніки, дендрології та лісової селекції. Email: s.kovalevsky@ukr.net

Цитування за ДСТУ: Легкий В. В., Ковалевський С. Б. Типологічне оцінювання лісових масивів Дубровицького лісництва, порушених унаслідок несанкціонованого видобутку бурштину. Науковий вісник НлтУ України. 2018, т. 28, № 8. С. 61-64.

Citation APA: Lehkyi, V. V., \& Kovalevskii, S. B. (2018). Typological estimation of forest massif of Dubrovytskyi forestry disturbed by unauthorised extraction of amber. Scientific Bulletin of UNFU, 28(8), 61-64. https://doi.org/10.15421/40280812 
\& Kyrychok, 2008; Shvydenko \& Ostapenko, 2001).

Сьогодні немає чітко встановленого порядку рекультивації земель, що зазнали антропогенного перетворення внаслідок несанкціонованого видобутку бурштину-сирцю, та відсутня законодавча база щодо врегулювання цієї проблеми.

Мета дослідження полягає в типологічному оцінюванні лісових масивів Дубровицького району, що зазнали антропогенного навантаження внаслідок несанкціонованого видобутку бурштину, в обгрунтуванні заходів щодо відновлення та збереження лісової системи на всіх рівнях їі розвитку.

Матеріали й методи дослідження. Матеріалами, які були використані для дослідженні цієї проблеми, була інформація Дубровицького лісництва, ДП "Дубровицьке ЛГ", інтернет-джерела, наукові статті, наукова література. Для раціонального дослідження поставленої проблеми було використано такі методи, як: аналітичні, спостереження, порівняння та польові методи досліджень.

Результати дослідження та їх обговорення. Під час дослідження проблеми несанкціонованого видобутку бурштину проаналізовано матеріали Державного агентства лісових ресурсів України, а також таксаційний опис Дубровицького лісництва ДП "Дубровицьке ЛГ". Провівши аналіз матеріалів і розрахункові операції, ми виокремили орієнтовні площі, які зазнали антропогенного перетворення. Результати дослідження навели у вигляді кругової діаграми (рис. 1). Аналізуючи дані діаграми, варто зазначити, що частка порушених земель є доволі значною й кожного дня зростає. Цей показник свідчить про значні втрати деревної сировини, недеревних ресурсів лісу, підросту, підліску та живого надгрунтового покриву. Водночас, із зазначеними вище втратами зростає клас пожежної небезпеки на цих територіях, що може призвести до неминучих наслідків. Порушені лісові ділянки є джерелом виникнення та поширення шкідників лісу і грибкових захворювань.

Порушена площа

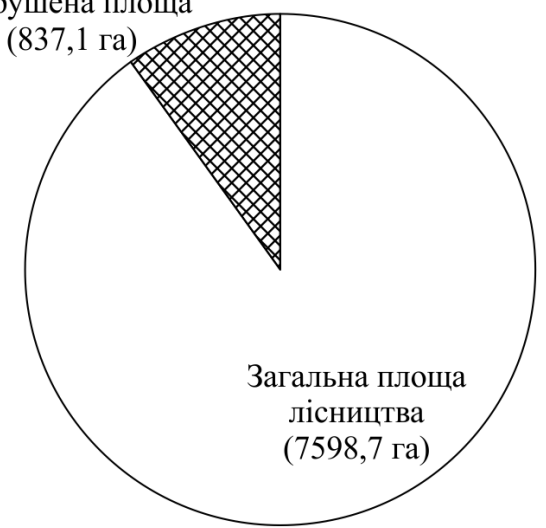

Рис. 1. Відношення загальної площі лісництва до порушеної

Продовжуючи дослідження проблеми несанкціонованого видобутку бурштину на територіях Дубровицького лісництва, проаналізуємо типологічну складову лісу, яка зазнала перетворень. Під час аналізу встановлено площі порушених типів лісорослинних умов (табл. 1).

Аналіз наведених у табл. 1 даних показує, що найбільша частка порушених земель належить до типу лісорослинних умов С3 - вологі сугруди. Це відносно ба- гаті грунти: супіски із прошарками суглинків. Рослинність - оліготрофна, мезотрофна і мегатрофна, причому перші дві групи мають виключний розвиток. У відповідному ТЛУ сосна звичайна зростає за I-I ${ }^{\mathrm{a}}$, ялина європейська - за I-II, дуб звичайний - за I-III, бук лісовий за II бонітетами. Також високий показник порушених площ має ТЛУ $\mathrm{B}_{3}$ - вологий субір. Це середньо- і сильнопідзолисті, глинясто-піщані, супіщані, іноді - суглинкові добре зволожені грунти. Шар грубого гумусу досягає 5-10 см. Причиною перетворення окремих ТЛУ, на нашу думку, може бути взаємозв'язок між типами лісорослинних умов та покладами бурштину.

Табл. 1. Площі порушених ТЛУ та їх співвідношення, \%

\begin{tabular}{|c|c|c|c|}
\hline $\begin{array}{c}\text { Тип } \\
\text { лісу }\end{array}$ & $\begin{array}{c}\text { Загальна площа від- } \\
\text { повідного ТЛУ (на } \\
\text { порушних землях), } \\
\text { га }\end{array}$ & $\begin{array}{c}\text { Порушена пло- } \\
\text { ща відповідно- } \\
\text { го ТЛУ, га }\end{array}$ & $\begin{array}{c}\text { Частка від за- } \\
\text { гальної площі } \\
\text { лісництва, \% }\end{array}$ \\
\hline $\mathrm{B}_{2}$ & 4,20 & 4,00 & 0,05 \\
\hline $\mathrm{B}_{3}$ & 180,20 & 101,00 & 1,33 \\
\hline $\mathrm{B}_{4}$ & 24,60 & 16,00 & 0,21 \\
\hline $\mathrm{B}_{5}$ & 4,10 & 3,50 & 0,05 \\
\hline $\mathrm{C}_{2}$ & 47,70 & 13,90 & 0,18 \\
\hline $\mathrm{C}_{3}$ & 917,10 & 603,50 & 7,94 \\
\hline $\mathrm{C}_{4}$ & 120,00 & 83,90 & 1,10 \\
\hline $\mathrm{C}_{5}$ & 17,30 & 11,30 & 0,15 \\
\hline $\begin{array}{c}\mathrm{Bcьо-} \\
\text { го }\end{array}$ & 1315,20 & 837,1 & 11,02 \\
\hline
\end{tabular}

Продовжуючи дослідження, не могли оминути співвідношення між порушеними площами та віковою складовою деревостану. У процесі дослідження встановлено, що найбільш деградованими є ділянки з середньовіковими насадженнями та молодняками (рис. 2), що призводить до деструкції у віковій структурі деревостану.

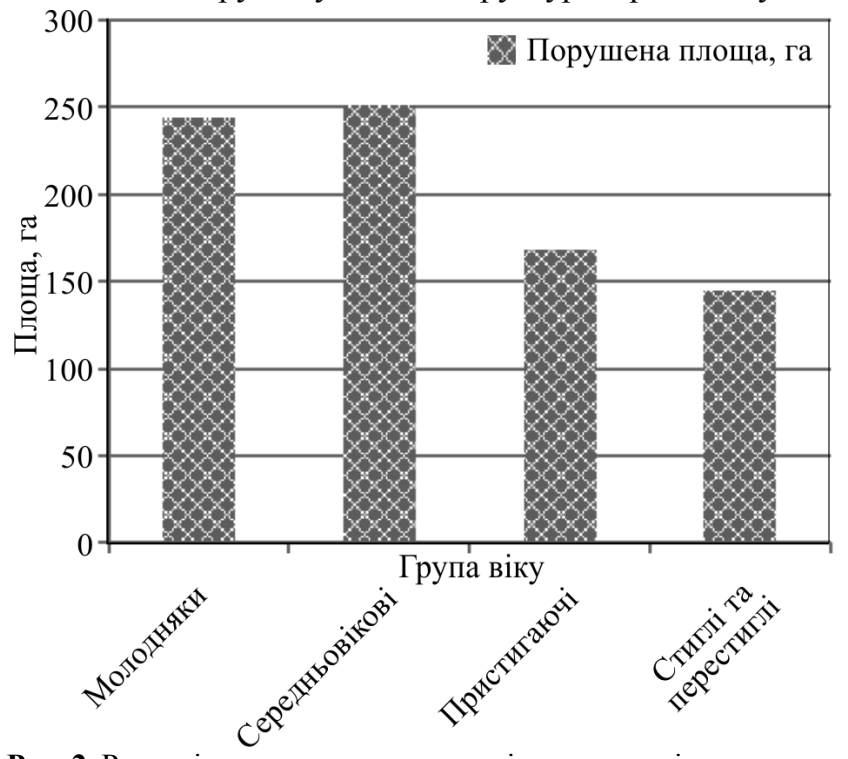

Рис. 2. Розподіл деградованих площ між групами віку

Згідно з Лісовим Кодексом України (ст. 41) (Lisovyi kodeks Ukrainy, 1994), у лісах виділяють також особливо захисні лісові ділянки, які мають обмежений режим користування: грунтозахисні ділянки лісу, ділянки вздовж берегів водойм, схилів, ярів і балок, галявин лісів на кордонах із безлісними територіями, місця проживання та поширення рідкісних і тих, які перебувають під загрозою зникнення, диких тварин, рослин.

Особливо негативним чинників для лісогосподарського підприємства є порушення ОЗЛД внаслідок несан- 
кціонованого видобутку бурштину, що призводить до зникнення рідкісних диких тварин та рослин, втрати захисних функцій лісу, реліктових насаджень і пам'яток iсторії. У цьому випадку підприємство зазнає втрат не стільки з економічного погляду, скільки з екологічного, які є неоціненними сьогодні. Об'єктом несанкціонованого промислу на територіях ОЗЛД є стиглі та перестійні лісові насадження. Саме вони характеризуються високими лісотаксаційними показниками й мають ключове еколого-економічне значення у функціонуванні Дубровицького лісництва, що, водночас, завдає значних збитків підприємству й галузі загалом. Досліджуючи ситуацію 3 антропогенним навантаженням на ОЗЛД внаслідок несанкціонованого промислу, встановлено площі порушених ТЛУ на цих територіях (табл. 2).

Табл. 2. Розподіл між порушеними площами

$$
\text { та ТЛУ на ОЗЛД }
$$

\begin{tabular}{|c|c|}
\hline \multicolumn{2}{|c|}{ Особливо захисні лісові ділянки } \\
\hline Тип лісу & Порушена площа відповідного ТЛУ, га \\
\hline $\mathrm{C}_{2}$ & 1,8 \\
\hline $\mathrm{C}_{3}$ & 51,9 \\
\hline $\mathrm{B}_{3}$ & 2,0 \\
\hline Всього & 55,7 \\
\hline
\end{tabular}

Отож, найбільшого перетворення на ОЗЛД зазнали вологі сугруди $-\mathrm{C}_{3}$, які характеризуються високими показниками продуктивності сосни звичайної. Для запобігання прояву несанкціонованого видобутку бурштину державна лісова охорона спільно $з$ поліцією постійно проводять рейди в місцях незаконного промислу. ДП "Дубровицьке лісове господарство" виконує роботи щодо засипання незаконно виритих котлованів у Дубровицькому лісництві, які були викопані для незаконного видобутку бурштину - сирцю.

Висновки і перспективи. У межах території Дубровицького лісництва спостерігають негативну тенденцію, яка пов'язана з порушенням екологічної рівноваги лісу на різних етапах біологічного розвитку внаслідок несанкціонованого видобутку бурштину. Частка порушених площ від лісового фонду Дубровицького лісництва становить понад 837 га, тобто $11 \%$ від загальної площі лісництва. Найбільш деградованими виявились такі типи лісорослинних умов, як: вологі та сирі сугруди, вологі субори, що становить понад 10 \% від загальної площі лісництва. За віковою структурою, найбільша частка порушених земель припадає на молодняки та середньовікові насадження, що призводить до порушень у віковій структурі деревостану.

Негативною тенденцією є процвітання несанкціонованого промислу на територіях особливо захисних лісових ділянок, що призводить до зникнення рідкісних диких тварин та рослин, втрати захисних функцій лісу, реліктових насаджень і пам'яток історії. На антропізованих площах спостерігають втрату верхнього родючого шару грунту й заміну його на малоцінний у господарському відношенні з невизначеним хімічним складом.

Позитивною тенденцією $є$ утворення куртин природного поновлення сосни звичайної та берези повислої на деградованих землях, що в перспективі може відіграти ключову роль у відновленні порушених земель.

\section{Перелік використаних джерел}

Kazymyr, M. M., \& Bedernichek, T. Yu. (2017). Rekultyvatsiia zemel porushenykh vnaslidok vydobutku burshtynu na Polissi: problemy ta perspektyvy. Ekonomika pryrodokorystuvannia: stan, problemy, perspektyvy: Materialy III Vseukrainskoi nauk.-prakt. Internet-konferentsii, (pp. 90-94), Mart, 13-20. Irpin: UDFSU. [In Ukrainian].

Lisovyi kodeks Ukrainy. (1994). Forest Code of Ukraine. 21.01.1994, № 3852 XII. [In Ukrainian].

Nadtochii, P. P. (2015). Ekologo-ekonomichna otsynka vplyuv diyalnosti, povzjazanoi z illegally vidobuvannjam burshtinu, on the stand dovkillya Zhytomyrschiny. Visnyk Zhytomyrskoho natsionalnoho ahroekolohichnoho universytetu, 1(1), 28-50. [In Ukrainian].

Poiasniuvalnyi lyst. (2002). Project for the organization and development of Dubrovytsia forestry, forest management, 260 p. [In Ukrainian].

Postanova KMU. (2016). Deiaki pytannia realizatsii pilotnoho proektu rekultyvatsii zemel lisohospodarskoho pryznachennia, porushenykh vnaslidok nezakonnoho vydobuvannia burshtynu. postanova KMU vid 30 lyst. 2016 r., № 1063. Retrieved from: http://zakon5.rada.gov.ua/laws/show/1063-2016-\%D0\%BF. [In Ukrainian].

Shvydenko, A. Y., \& Ostapenko, B. F. (2001). Forest Science. Chernivtsi: Zelena Bukovyna, 352 p. [In Ukrainian].

Spur, S. H., \& Barness, V. V. (1984). Forest Ecology. Moscow: Lesn. prom-st, 480 p. [In Russian].

Svyrydenko, V. Ie., Babich, O. H., \& Kyrychok, L. S. (2008). Forestry. Kyiv: Aristei, 544 p. [In Ukrainian].

Taxation Description. (2009). Taksatsiinyi opys zemelnykh dilianok lisovoho fondu Dubrovytskoho lisnytstva stanom na 01.01.2009 roku, 320 p. [In Ukrainian].

Национальный университет биоресурсов и природопользования Украины, г. Киев, Украина

\section{ТИПОЛОГИЧЕСКАЯ ОЦЕНКА ЛЕСНЫХ МАССИВОВ ДУБРОВИЦКОГО ЛЕСНИЧЕСТВА, НАРУШЕННЫХ В РЕЗУЛЬТАТЕ НЕСАНКЦИОНИРОВАННОЙ ДОБЫЧИ ЯНТАРЯ}

Приведены результаты исследования территории и лесных насаждений Дубровицкого лесничества, поврежденных в результате незаконной добычи янтаря. Выяснены масштабы антропизации типов лесорастительных условий, на основе чего выделены наиболее деградированные из них. Исследованы площади нарушенных лесных земель и установлено их процентное соотношение к общей площади кварталов Дубровицкого лесничества. Приведена краткая характеристика отдельных эдатопов. Исследованы и проанализированы соотношения между повреждёнными площадями и возрастной составляющей древостоя. Выделены возрастные группы древостоев, которые испытали наибольшее антропогенное преобразование вследствие несанкционированного промысла. Определен ряд сопутствующих проблем, связанных с добычей янтаря. Установлено распределение повреждённых площадей между возрастными группами и типами лесорастительных условий на особо защитных лесных участках. Охарактеризованы закономерности нарушения территорий особо защитных лесных участков, что приводит к исчезновению редких диких животных и растений, потери защитных функций леса, реликтовых насаждений и памятников истории. Выделены негативные последствия для лесохозяйственной отрасли, возникновение которых связано с добычей янтаря. Перечислены лесоводческие потери, которые несет предприятие за счет процветания несанкционированного промысла. Проанализированы потенциальные возможности естественного возобновления на антропизированных площадях.

Ключевые слова: тип лесорастительных условий; антропизация; янтарь. 


\section{TYPOLOGICAL ESTIMATION OF FOREST MASSIF OF DUBROVYTSKYI FORESTRY DISTURBED BY UNAUTHORISED EXTRACTION OF AMBER}

The problem that arose in the forests of Dubrovytskyi District as a result of unauthorized extraction of amber contributes to the rapid change in forest-related conditions in these areas. In areas where illegal fishing took place, significant transformations in the structure and mineral composition of the soil layer of forest lands are observed, completely or partially destroyed by live surface cover, undergrowth and growth, undergoes a significant transformation of conditions of location and anthropogenic pressure. Violation of the ecological balance of the forest at different stages of biological development can lead to irreversible consequences in the forestry industry. The study of the typology of disturbed forest landscapes of Dubrovytskyi District makes enables assessing the full spectrum of forestry problems which industry workers face and identifying priority measures for regulating this situation. The share of disturbed lands is quite substantial and increases every day. This indicator shows significant losses of wood raw materials, nonwood resources of the forest, growth, subsurface and living superficial cover. Disturbed forest areas are the source of the occurrence and spread of forest pests and fungal diseases. The most degraded are areas with medieval plantations and young, which leads to destruction in the age structure of the tree-stands. The object of unauthorized fishing in the territories of especially protective forest areas is ripe and overgrown forest plantations. They are characterized by high forest-taxis and have a key ecological and economic significance in the operation of Dubrovytskyi Forestry, which in turn causes significant damage to the enterprise and the industry as a whole. Within the territory of Dubrovytskyi Forestry there is a negative trend, which is associated with violation of the ecological balance of the forest at various stages of biological development, as a result of unauthorized extraction of amber. The share of disturbed areas from the forest fund of Dubrovytskyi Forestry is $11 \%$ of its total area. According to the age structure, the largest proportion of disturbed lands falls on youngsters and medieval plantations, which in turn leads to violations of the age structure of the tree-stands.

Keywords: type of forest conditions; anthropization; amber. 